\title{
Ramadan Fasting and Weight-Lifting Training on Vascular Volumes and Hematological Profiles in Young Male Weight-Lifters
}

\author{
Seyed Morteza Tayebi \\ Department of Physical Education and Sport Sciences \\ Ayatollah Amoli Islamic Azad University, Amol, Iran \\ E-mail: s.m.tayebi@iauamol.ac.ir \\ Parichehr Hanachi (Corresponding author) \\ Biology Department, Biochemistry Unite, Faculty of Basic Science \\ Alzahra University, Vanak St, Tehran, Iran \\ Tel: 9821-8804-4040Ｅ-mail: Hanachi_wrc@yahoo.com \\ Abbass Ghanbari Niaki \\ Department of Physical Education and Sport Sciences \\ Mazandaran University, Babolsar, Iran \\ E-mail: ghanbari@umz.ac.ir \\ Parvaneh Nazar Ali \\ Faculty of Sport Science, Alzahra University, Tehran Iran \\ E-mail: nazarali@yahoo.com \\ Fatemeh Ghorban-alizadeh Ghaziani \\ Department of Physical Education and Sport Sciences \\ Ayatollah Amoli Islamic Azad University, Amol, Iran \\ E-mail: F_6839@yahoo.com
}

\begin{abstract}
During the holy month of Ramadan the quality of food and eating patterns changed and drinking will be stopped for at least 10 to 16 hours on the basis lunar calendar. The effects of exercise and fasting solely or combined on metabolic and hematologic responses well established. The purpose of the present study was to study the effects of Ramadan fasting with or without weight-lifting training on vascular volumes and selected hematological indices in young male weight-lifters. Blood samples were taken at $24 \mathrm{~h}$ before and $24 \mathrm{~h}$ after the last day of holy Ramadan fasting period and weight-lifting training for determination of the selected red and white blood cells compositions. The Vascular volumes (Blood, Red cells, and plasma volumes) were determined and calculated by using both hemoglobin and hematocrit estimations before and after Ramadan fasting with or without weight-lifting training. The results indicate that red cell volume and $\mathrm{MCHC}$ were significantly decreased and increased in fasting group $(\mathrm{P}<0.05)$ respectively. The percentages of hematocrit were significantly low in both training and fasting groups. A higher and significant platelet count was found in training group. The present data indicate that weight-lifting training during the holy Ramadan in compare to fasting had no impact on red and white cells composition exception on platelet count and Hematocrit. A decrease in Hematocrit might be due to the incomplete dehydration period which amplified by stop drinking and nutritional habits during the holy Ramadan.
\end{abstract}

Keywords: Hematocrit, Ramadan, Weight-lifting, Platelet, Vascular volume 


\section{Introduction}

There have been few studies on the effect of Ramadan fasting on red blood cell and its parameters (Sarraf-Zadegan et al, 2000; Furuncuoglu et al, 2007), white blood cell and its variables and platelets (Latifynia et al, 2007; Aybak et al, 19996). During the month of Ramadan, Food and fluid intake frequency and quantity are decreased and those qualities are changed to the consumption of foods that contain more carbohydrates and starches. Also sleep and physical activity habits are changed as reduction (Meckel et al, 2008). It is important to know the effect of this kind of fasting on people's life especially with or without exercise.

Ramadan et al, (1999) investigated the effects of the Ramadan fasting on body composition and some plasma component, hematology, and responses to steady state sub-maximal exercise in six physically active and seven sedentary men. They indicated, that platelet count was lower in both physically active and sedentary men by the end of Ramadan fasting. They concluded that deficits or redistribution of specific micronutrients may account for reductions in platelet counts. Ramadan, (2002), explored the effect of Ramadan fast on body composition, plasma constituents, hematology, and cardio respiratory responses to constant sub-maximal exercise. Also, Bouhlel et al, (2006) who investigated the effect of sub-maximal exercise in nine trained rugby player in three occasions and two statuses: before, first week, last week of Ramadan fasting, and at rest and acute exercise.

None of these studies looked at the parallel effect of Ramadan fasting and weight-lifting or resistance training on vascular volumes, and selected hematological parameters. Hence, we conducted this study in the month of Ramadan on healthy samples of Iranian young male Weight-lifter to investigate the effects of Ramadan fasting and weight-lifting exercise on vascular volumes, and selected hematological parameters.

\section{Materials and methods}

\subsection{Subjects and research design}

Forty healthy young male weight-lifters were chosen by the random sampling. The study was conducted on before and after $30^{\text {th }}$ day of the Ramadan month on, 2006.

All subjects were asked to complete a medical examination and a medical questionnaire to ensure that they were not taking any medication, were free of cardiac, respiratory, renal, and metabolic diseases. The subjects were assigned either as a control-no fasted $(\mathrm{CNF})(\mathrm{n}=10)$, control-fasted $(\mathrm{n}=10)(\mathrm{CF})$, training-no fasted $(\mathrm{TNF})(\mathrm{n}=$ 10), and training-fasted (TF) $(n=10)$ groups. The study was approved by the ethic committee of the School of Medical Sciences of Shomal University, Iran and conducted in accordance with the policy statement of the Declaration of the Iranian Ministry of health.

\subsection{Exercise training protocol}

The subjects were instructed to follow a normal lifestyle maintaining daily habits, to avoid any medications. Before the main trial, participants were taken to the weight room three times. On the any three visits of all the participants performed strength test to determine their one repetition maximum (1-RM) for each of the exercises, employed in the study. The "TNS" and "TF" groups were asked to performed weight lifting techniques and hypertrophy type of exercise (3sessions/week, 90min/session).

\subsection{Blood collection}

Blood samples were obtained from antecubital vein at $24 \mathrm{~h}$ before and $24 \mathrm{~h}$ after one month of fasting and collected in test tubes containing EDTA. Subjects were $12 \mathrm{~h}$ overnight fast in the any two trials. The Plasma was separated by centrifugation within 15 min of collection.

\subsection{Hematological parameters and analysis}

Red blood cell counts and its related compositions such as; Hemoglobin (Hb), Hematocrit (HCT), Mean corpuscular volume (MCV), Mean corpuscular hemoglobin (MCH), Mean corpuscular hemoglobin concentration (MCHC), and the red blood cell distribution width (RDW) were measured. In addition, white blood cell count (WBC), and its compositions such as; polynuclear, neutrophils (NEUT), eosinophil (EOS) and mononuclear lymphocytes (LYMP) and monocytes (MON), cells were also determined. Platelet count (PLT), mean platelet volume (MPV), platelet distribution width (PDW) and platelet large cell-rate (PLC-R) was determined using the system K-4500 automated hematology analyzer. Vascular blood, red cell (RCV), and plasma (PV) volumes were calculated by using the Dill and Costill, (1974) method.

\subsection{Statistical Analysis}

The data were performed with using SPSS 15.0 (Statistical Package for Social Science). The results were analyzed using the 2-tailed $t$ test and One-Way ANOVA, PostHoc: "Tukey" and calculated coefficient correlation before 
and after Ramadan fasting with or without weight-lifting training. The statistical significance was accepted at $\mathrm{P}<$ 0.05 .

\section{Results}

The mean age of participants was $21.3 \pm 1.6$ years. There were no significant differences in plasma volumes of assigned groups before the Ramadan fasting. The same results were observed after the Ramadan fasting and exercise protocol except CNF group which had a higher and significant $(P<0.05)$ plasma volume. A significant $(\mathrm{P}<0.05)$ weight reduction was only found in $\mathrm{CF}$ and TF groups (Table 1). Vascular volumes include blood volume (BV) and red cell volume (RCV) was not changed significantly in C, T and F-T groups. However, in F group, RCV was showed significant $(\mathrm{p}<0.05)$ decrease in the $1^{\text {th }}$ day before Ramadan, compared with $30^{\text {th }}$ day of Ramadan month after the exercise protocol (Table 2).

Hematological parameters such as; RBC, Hb, HCT, MCV, MCH, MCHC, and RDW were not changed significantly in CNF, and F-T groups, however significant $(p<0.05)$ decrease was found in HCT in TNF and CF groups and $\mathrm{MCHC}$ increase significantly $(\mathrm{p}<0.05)$ in $\mathrm{CF}$ group. Although other variables in both TNF and FG groups were not changed significantly (Table 3 ).

In all groups WBC, LYMP, NEUT, MON, and EOS were not changed significantly. However variables as PLT, MPV, PDW, and PLC-R were not changed significantly in CNF, CF and F-T, however in T group, significant $(p<0.05)$ increase was found in PLT levels, the other variables were not changed significantly in the 1 day before Ramadan compared with $30^{\text {th }}$ day of Ramadan month after the exercise protocol ( Figure. 1).

\section{Discussion}

The main findings of the present study were a significant body weight reduction in CNF and TF groups, red blood cells volume in CF group, and a higher MCHC in CF group. A lower RVC might be due to a reduction in HCT and increase in MCHC. Significant increase in PV as hemodilution could show a cardiovascular adaptation to fasting and long-term thirst during day. Another likely reason for hemodilution was environmental factors (Heinickes et al, 2001) and the time of blood sampling (Sarraf-Zadegan et al 2000) as blood samples was collected at 24h after last day of Ramadan fasting.

In this regards our results were agreement with Sarraf-Zadegan et al, (2000) who reported that in their experimental condition the levels of RBC remained unchanged, but the levels of HCT decreased following the Ramadan fasting period. However, we didn't observe any significant changes in RBC and $\mathrm{Hb}$. Moreover, unchanged factors of RBC morphology including $\mathrm{MCV}, \mathrm{MCH}$ and $\mathrm{RDW}$, could show a cardiovascular adaptation to fasting.

Our results showed that HCT decreased significantly in T and F groups, but this didn't accompany with significant changes in RBC, Hb, MCV, MCH, MCHC and RDW. Schumacher et al (2000) observed significant reduction in $\mathrm{HCT}, \mathrm{Hb}$ and \%11.14 increases in PV of cyclist national team of Germany after competition season and reported that these changes related to training duration and intensity, as they found a higher level of HCT and Hb in period of reduction in training intensity and frequency compared with competition season. Various mechanism can be due to these adaptations such as; haemodilution or plasma volume increases (Convertino et al 1991), exercise hemolysis (Selby et al 1986) and erythropoietin reduction in adaptation to exercise training (Schumacher et al 2000). However, in our study, RBC didn't change significantly in TG; hence reduction in HCT was independent in RBC. However RCV reduction was significant $(\mathrm{p}<0.05)$, while elevation in $\mathrm{BV}$ was very high and likely it induced significant decrease in HCT (Selby et al 1994, Schumacher et al 2000).

Sarraf-Zadegan et al, (2000) showed that WBC didn't change significantly when the mean levels of fasting period in Ramadan compared with two months later mean concentrations. Similarly, in our study, not only WBC, LYMP, NEUT, MON and EOS didn't change significantly in any groups.

Exercise training also adjusts function of immune system, particularly when training loads are high suggesting a general reduction in immune function (Gleeson, 2002). Circulating leukocytes numbers in athletes at rest are overall lower compared with sedentary people (Mackinnon, 1998 a,b). A low white blood cells count may increase from the haemodilution related to training, or may describe changed kinetic of leukocytes following a decreased release from the bone marrow (Keen et al, 1995). Functions of neutrophils were reduced during high-intensity training periods but unaltered in athletes during a period of low-training (Hack et al, 1992; Baj et al, 1994).

Hence, with respect to our results, Ramadan fasting, a low-training period of weight-lifting with moderate intensity, and also parallel performing of this type of exercise training accompanied Ramadan fasting, didn't effect on this immune indices and almost, this results were concomitant with earlier evidences. 
Aybak et al, (2007); Furuncuoglu et al, 1996, also found that PLT didn't change during Ramadan fasting that confirm our results. But in conflict to our results, Sarraf-Zadegan et al, (2000), showed higher PLT mean levels during Ramadan fasting compared with two months later mean concentrations.

However, fasting in untrained weight-lifters caused significant reduction in red cell volume and insignificant changes in other factors, hence induced not bad effects; but, regular weight-lifting training in non-fast subjects resulted significant elevation in blood platelet count and likely increased their cardiovascular risk. But this results not enough for conclusion, because this may related to final blood sampling time and beside, how recovery done after last training session. A decrease in Hematocrit might be due to the incomplete dehydration period which amplified by stop drinking and nutritional habits during the holy Ramadan. It seems that the coagulative effect of training with repetitive short-term fasting period has to be considered in future study. Therefore, we recommended that in further investigation about effects of weight-lifting exercise training through Ramadan month of low-period adaptation, would note blood sampling within $48 \mathrm{~h}$ after post hypertrophic exercise.

\section{Acknowledgment}

The authors would like to acknowledge University of Shomal, Mazandaran, Iran for supporting this study.

\section{Refrences}

Aybak M, Türkoğlu A, Sermet A, Denli O. (1996). Effect of Ramadan fasting on platelet aggregation in healthy male subjects, 73(6), 552-556.

Baj Z, Kantorski J, Majewska E, Zeman K, Pokoca L, Fornalczyk E et al. (1994). Immunological status of competitive cyclists before and after the training season. Int J Sports Med, 15, 319-324.

Bouhlel E, Salhi Z, Bouhlel H, Mdella S, Amamou A, Zaouali M, et al. (2006). Effect of Ramadan fasting on fuel oxidation during exercise in trained male rugby players, 32(6), 617-624.

Convertino V.A. (December 1991). Blood volume: its adaptation to endurance training. Medicine \& Science in Sports \& Exercise, 23(12):1338-1348.

Dill DB, Costill DL. (1974). Calculation of percentage changes in volume of blood plasma and red cell in dehydration. J Appl Physiol, 37 (2), 103-106.

Furuncuoglu Y, Karaca E, Aras Sükrü and Yönem Arif. (2007). Metabolic, Biochemical and Psychiatric Alterations in Healthy Subjects During Ramadan. Pakistan Journal of Nutrition, 6 (3), 209-211.

Gleeson M. (2002). Biochemical and Immunological markers of overtraining Review Article. Journal of Sports Science and Medicine, 1, 31-41.

Hack V, Strobel G, Rau JP, and Weicker H. (1992). The effect of maximal exercise on the activity of neutrophil granulocytes in highly trained athletes in a moderate training period. Eur J Appl Physiol, 65, 520-524.

Heinicke K, Wolfarth B, Winchenbach P, Biermann B, Schmid A, Huber G, et al. (2001). Blood Volume and Hemoglobin Mass in Elite Athletes of Different Disciplines. Int J Sports Med, 22, 504-512.

Keen, P., Mccarthy, D.A., Passfield, L., Shaker, H.A.A. and Wade, A.J. (1995). Leukocyte and erythrocyte counts during a multi-stage cycling race ('The Milk Race'). British Journal of Sports Medicine, 29, 61-65.

Latifynia A, Vojgani M, Abofazeli T and Jafarieh H. (2007). Circulating immune complex during Ramadan. 19(2), 15-18.

Mackinnon, L.T. (1998a). Effects of overreaching and overtraining on immune function. In: Overtraining In Sport. Ed: Kreider, R.B., Fry, A.C., O’toole, M.L. Champaign Il: Human Kinetics, 219-241.

Mackinnon, L.T. (1998b). Exercise and Immunology. $2^{\text {nd }}$ Edition. Champaign Il: Human Kinetics.

Meckel Y, Ismaeel A, Eliakim A. (2008). The effect of the Ramadan fast on physical performance and dietary habits in adolescent soccer players, 102(6), 651-657.

Ramadan J, Telahoun G, Al-Zaid NS, Barac-Nieto M. (1999). Responses to exercise, fluid, and energy balances during Ramadan in sedentary and active males. Nutrition, 15(10), 735-739.

Ramadan J. (2002). Does fasting during Ramadan alter body composition, blood constituents and physical performance. Med Princ Pract, 11 (2), 41-46.

Sarraf-Zadegan N, Atashi M, Naderi Gholam A, Baghai Abdoul M, Asgary S, Fatehifar Mohammad R, et al. (2000). The Effect of Fasting in Ramadan on the Values and Interrelations between Biochemical, Coagulation and Hematological Factors. Ann Saudi Med, 20 (5-6), 377-381. 
Schumacher YO, Grathwohl D, Barturen JM, Wollenweber M, Heinrich L, Schmid A, Huber G, Keul J. (2000). Haemoglobin, haematocrit and red blood cell indices in elite cyclists. Are the control values for blood testing valid? Int J Sports Med., 21(5):380-5.

Selby G.B, Eichner E.R. (1994). Hematocrit and performance: the effect of endurance training on blood volume. Seminars in hematology, 31:22, 122-127.

Selby GB, Eichner ER. (1986). Endurance swimming, intravascular hemolysis, anemia, and iron depletion. New perspective on athlete's anemia. Am J Med., 81(5):791-4.

Table 1. Values of plasma volume (PV) and body weight factors. (Mean \pm SE) in the 1 day before Ramadan (pre) compared with 30th day of Ramadan month after (post) the exercise protocol in different groups

\begin{tabular}{clcccl}
\hline Groups & \multicolumn{2}{c}{ Variables } & Pre & Post & p-Value \\
\hline \multirow{2}{*}{ CNF } & PV & $(\mathrm{mL})$ & $52.4 \pm 1.79$ & $54.8 \pm 1.7$ & 0.43 \\
& BW & $(\mathrm{Kg})$ & $76.38 \pm 3.05$ & $76.22 \pm 3.04$ & 0.30 \\
& & & & & \\
TNF & PV & $(\mathrm{mL})$ & $53.26 \pm 1.26$ & $64.4 \pm 7.03$ & 0.12 \\
& BW & $(\mathrm{Kg})$ & $89.28 \pm 6.00$ & $89.47 \pm 5.98$ & 0.27 \\
CF & & & & & \\
& PV & $(\mathrm{mL})$ & $53.38 \pm 1.14$ & $55.5 \pm 1.11$ & $0.034^{*}$ \\
& BW & $(\mathrm{Kg})$ & $90.00 \pm 4.55$ & $89.14 \pm 4.48$ & $0.013^{*}$ \\
& & & & & \\
F-T & PV & $(\mathrm{mL})$ & $52.65 \pm 1.54$ & $54.2 \pm 2.38$ & 0.50 \\
& BW & $(\mathrm{Kg})$ & $92.28 \pm 4.59$ & $91.40 \pm 4.63$ & $0.007^{* *}$ \\
\hline
\end{tabular}

*- Statistical significance was accepted at $\mathrm{P} \leq 0.05$. **. Statistical significance was accepted at $\mathrm{P} \leq$ 0.01. (PV) plasma volume. Data are mean \pm S.E.M. Control-no fasted (CNF), control-fasted (CF), training-no fasted (TNF), and training-fasted (TF) groups.

Table 2. Values of BV and RCV. (Mean \pm SE) in the 1 day before Ramadan (Pre) compared with 30th day of Ramadan month after (Post) the exercise protocol

\begin{tabular}{clccl}
\hline Groups & (ml) & Pre & Post & p-Value \\
\hline CNF & BV & $100 \pm 0.0$ & $102.8 \pm 6.9$ & 0.41 \\
$(\mathrm{n}=10)$ & RCV & $47.6 \pm 1.79$ & $47.9 \pm 1.98$ & 0.45 \\
& & & & \\
TNF & BV & $100 \pm 0.0$ & $110.81 \pm 7.09$ & 0.16 \\
$(\mathrm{n}=10)$ & RCV & $46.73 \pm 1.26$ & $46.4 \pm 1.16$ & 0.59 \\
& & & & \\
CF & BV & $100 \pm 0.0$ & $101.0 \pm 0.88$ & 0.28 \\
$(\mathrm{n}=10)$ & RCV & $46.62 \pm 1.14$ & $45.4 \pm 1.4$ & $0.024^{*}$ \\
F-T & BV & $100 \pm 0.0$ & $100.67 \pm 2.2$ & 0.76 \\
$(\mathrm{n}=10)$ & RCV & $47.34 \pm 1.54$ & $46.40 \pm 1.25$ & 0.12 \\
\hline
\end{tabular}

Data are mean \pm S.E.M. *- Statistical significance was accepted at $\mathrm{P} \leq 0.05$. Control-no fasted (CNF), control-fasted (CF), training-no fasted (TNF), and training-fasted (TF) groups. 
Table 3. Values of RBC factors in the 1 day before(Pre) Ramadan compared with 30th day of Ramadan month after(Post) the exercise protocol

\begin{tabular}{|c|c|c|c|c|c|}
\hline \multirow[t]{2}{*}{ Groups } & \multicolumn{2}{|c|}{ Variables } & \multirow{2}{*}{$\frac{\text { Pre }}{5.32 \pm 0.08}$} & \multirow{2}{*}{$\frac{\text { Post }}{5.34 \pm 0.1}$} & \multirow{2}{*}{$\frac{\text { p-Value }}{0.75}$} \\
\hline & RBC & $\left(10^{6} / \mu \mathrm{L}\right)$ & & & \\
\hline \multirow{6}{*}{ CNF } & $\mathbf{H b}$ & $(g / L)$ & $15.66 \pm 0.52$ & $15.24 \pm 0.29$ & 0.42 \\
\hline & HCT & $(\%)$ & $47.60 \pm 1.79$ & $46.58 \pm 1.01$ & 0.47 \\
\hline & MCV & $(\mathrm{fL})$ & $89.44 \pm 2.82$ & $92.10 \pm 4.76$ & 0.39 \\
\hline & МСH & (pg/cell) & $29.44 \pm 0.94$ & $30.13 \pm 1.34$ & 0.45 \\
\hline & МCHC & $(\mathrm{g} / \mathrm{dL})$ & $32.94 \pm 0.34$ & $33.60 \pm 0.79$ & 0.49 \\
\hline & RDW & $(\%)$ & $12.26 \pm 0.69$ & $13.15 \pm 0.35$ & 0.43 \\
\hline \multirow{7}{*}{ TNF } & RBC & $\left(10^{6} / \mu \mathrm{L}\right)$ & $5.81 \pm 0.18$ & $5.83 \pm 0.14$ & 0.75 \\
\hline & $\mathbf{H b}$ & $(\mathrm{g} / \mathrm{L})$ & $15.36 \pm 0.48$ & $14.24 \pm 0.86$ & 0.127 \\
\hline & HCT & $(\%)$ & $46.73 \pm 1.26$ & $42.86 \pm 2.21$ & $0.045^{*}$ \\
\hline & MCV & $(\mathrm{fL})$ & $80.94 \pm 3.07$ & $89.10 \pm 7.26$ & 0.24 \\
\hline & МСH & (pg/cell) & $26.65 \pm 1.16$ & $29.35 \pm 2.14$ & 0.16 \\
\hline & МCHC & $(\mathrm{g} / \mathrm{dL})$ & $32.85 \pm 0.29$ & $36.49 \pm 1.93$ & 0.08 \\
\hline & RDW & $(\%)$ & $13.35 \pm 0.42$ & $14.82 \pm 1.00$ & 0.19 \\
\hline \multirow{7}{*}{$\mathrm{CF}$} & RBC & $\left(10^{6} / \mu \mathrm{L}\right)$ & $5.75 \pm 0.17$ & $5.69 \pm 0.17$ & 0.48 \\
\hline & $\mathbf{H b}$ & $(g / L)$ & $15.22 \pm 0.43$ & $15.06 \pm 0.36$ & 0.28 \\
\hline & HCT & $(\%)$ & $46.62 \pm 1.14$ & $44.92 \pm 1.14$ & $0.009^{* * *}$ \\
\hline & MCV & $(\mathrm{fL})$ & $81.64 \pm 2.81$ & $80.96 \pm 2.69$ & 0.48 \\
\hline & МСH & (pg/cell) & $26.67 \pm 1.02$ & $27.15 \pm 0.95$ & 0.23 \\
\hline & MCHC & $(\mathrm{g} / \mathrm{dL})$ & $32.61 \pm 0.24$ & $33.88 \pm 0.33$ & $0.01^{* *}$ \\
\hline & RDW & $(\%)$ & $13.06 \pm 0.41$ & $13.15 \pm 0.57$ & 0.66 \\
\hline \multirow{7}{*}{ F-T } & $\mathbf{R B C}$ & $\left(10^{6} / \mu \mathrm{L}\right)$ & $5.85 \pm 0.2$ & $5.98 \pm 0.2$ & 0.11 \\
\hline & $\mathbf{H b}$ & $(g / L)$ & $15.4 \pm 0.57$ & $15.35 \pm 0.64$ & 0.88 \\
\hline & HCT & $(\%)$ & $47.34 \pm 1.54$ & $46.22 \pm 1.45$ & 0.37 \\
\hline & MCV & (fL) & $81.55 \pm 3.81$ & $78.53 \pm 3.30$ & 0.11 \\
\hline & МCH & (pg/cell) & $26.55 \pm 1.33$ & $26.07 \pm 0.30$ & 0.40 \\
\hline & МCHC & $(\mathrm{g} / \mathrm{dL})$ & $32.48 \pm 0.3$ & $33.31 \pm 0.72$ & 0.34 \\
\hline & RDW & $(\%)$ & $13.06 \pm 0.49$ & $13.38 \pm 0.62$ & 0.32 \\
\hline
\end{tabular}

*- Statistical significance was accepted at $\mathrm{P} \leq 0.05$. **- Statistical significance was accepted at $\mathrm{P} \leq 0.01$. (RBC): red blood cell count. (Hb): hemoglobin. (HCT): hematocrit. (MCV): mean corpuscular volume. (MCH): mean corpuscular hemoglobin. (MCHC): mean corpuscular hemoglobin concentration. (RDW): red cell distribution width. 


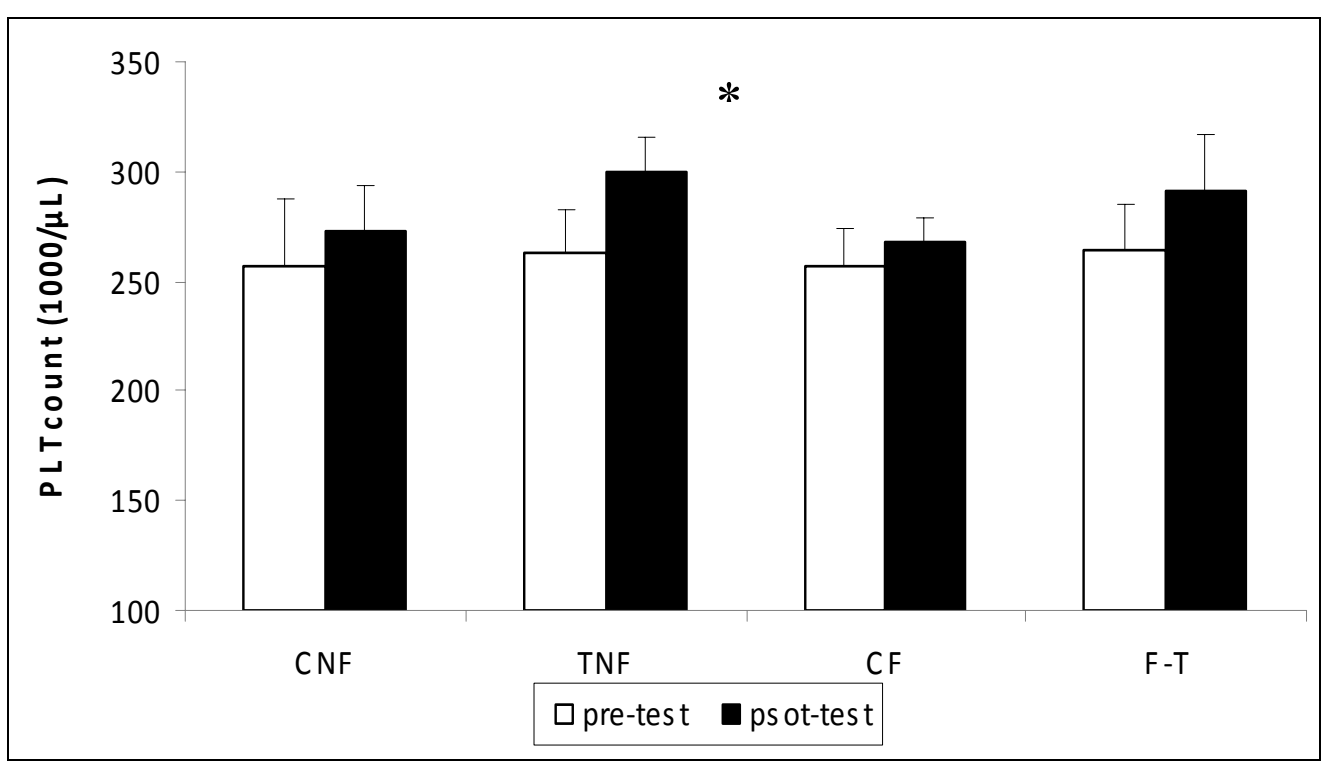

Figure 1. Platelet count $\left(10^{3} / \mu \mathrm{L}\right)$ of young male weight-lifters. *- Statistical significance was consider at $\mathrm{P} \leq 0.05$. Control-no fasted (CNF), control-fasted (CF), training-no fasted (TNF), and training-fasted (TF) groups 